\title{
Estimating the Sequestration Potential of Organic Carbon in Forest Soils in the Central Middle Atlas: A Tool to Fight Climate Change
}

\author{
Mohamed El Mderssa ${ }^{1 *}$, Hassan Benjelloun ${ }^{2}$, Hafida Zaher $^{2}$, Omar Zennouhi $^{1}$, Laila Nassiri ${ }^{1}$, \\ and Jamal Ibijbijen ${ }^{1}$
}

${ }^{1}$ Faculty of Sciences, Moulay Ismail University, B.P. 11201, Zitoune, Meknes, Morocco; ${ }^{2}$ National School of Forest Engineering, Sale-Tabriquet, Morocco

Received: January 16, 2019 / Accepted: March 2, 2019

\begin{abstract}
Soil organic carbon sequestration is an important matter in international negotiations to fight climate change through a reduction in greenhouse gas (GHG) emissions. This study was carried out in the forests of the Moroccan Central Middle Atlas, with the objective of determining the storage of carbon in the high organo-mineral layer of soils $(<30 \mathrm{~cm}$ deep) and under different spontaneous forest species in this area. It shows that the soil organic carbon stock (SOCS) in these forest ecosystems is higher in green oak and deciduous zeen oak forest stands, recording 264.73 and $251.54 \mathrm{t} /$ ha respectively on a basaltic substrate followed by cedar (resinous species) $(178.07 \mathrm{t} / \mathrm{ha})$. Mixed forest stands come at last with low SOCS (109.02 $\mathrm{t} / \mathrm{ha})$. This variation may be attributed to several factors, mainly the type of vegetation, the physical and chemical soil properties and soil type of the studied area.
\end{abstract}

Keywords: Sequestration, Central Middle Atlas, Organic carbon, Stock.

\footnotetext{
*Corresponding author: elmderssa.enfi@gmail.com

This is an Open Access article distributed under the terms of the Creative Commons Attribution License (http://creativecommons.org/licenses/by/3.0/), which permits unrestricted use, distribution, and reproduction in any medium, provided the original work is properly cited.
}

\section{Introduction}

The quantification of the organic carbon stock in forest ecosystems is to well understand the general carbon cycling in these ecosystems. Indeed, this quantity, in forest soil, is the result of the balance between the net primary production of vegetation and the decomposition of organic matter (Liski \& Westman, 1997). These two processes depend on climatic conditions, mainly temperature and humidity. However, forest soils may be a significant source of $\mathrm{CO}_{2}$ as a result of global warming, which lead to a mineralization of organic matter higher than the net primary production of vegetation (Liski, 1999, Bernoux et al., 2005). Every change in the organic carbon reservoir in the soil can significantly affect the concentration of $\mathrm{CO}_{2}$ in the atmosphere, since the soil contains twice as much carbon as the atmosphere (Schlesinger 1977; Post et al., 1982; Watson et al., 1990).

In addition, each tree species has different functional characteristics that allow it to have a unique influence on its environment, including the soil on which it grows. For example, depending on differences in shade tolerance, foliage persistence (evergreen vs. deciduous leaves), evapotranspiration capacity, and composition of the herbaceous stratum, soil moisture and temperature conditions may vary depending on stand type (Lag- 
anière et al., 2011).

Apart from the influence that a single tree species can have on its environment, mixing two or more tree species in mixed stands could have an impact on carbon sequestration in soils.

The present study aims to partially fill this knowledge gap, especially with regard to the quantification of carbon stock in forest soils as a result of the forest composition comprising four natural species, namely Cedar, Maritime Pine, Green Oak and Zeen Oak in three types of forest stands in the Moroccan Central Middle Atlas, namely the south of Jbel Aoua, Azrou and Jaaba forests.

\section{Materials and Methods}

\section{Description of the Study Areas}

This study was carried out in three natural forests of the Central Middle Atlas, namely the forests of south of Jbel Aoua, Azrou and Jaaba (Figure 1).

\section{The South of Jbel Aoua Forest}

The South of Jbel Aoua forest covers an area of 7865.42 ha. It is composed of a green oak coppice, a maritime pine grove and a cedar grove. The geological formations of the area are dominated by lower Jurassic (or lias) formations, which include sandy dolomites and dolomitic limestones. Two types of soils are described in the region. Soils developed on hard limestone namely fersialitic red soils and soils developed on sandy dolomite which are para rendzine that are relatively rare. The climate in the area is of a mediterranean type, the drought period is 5.5 months (mid-May - late October) and that the bioclimate is subhumid of cold variant (HCEFLCD, 2007).

\section{Azrou Forest}

Located on the northern edge of the Middle Atlas Plateau, the Azrou Forest covers an area of 17806.79 ha. This forest is characterized by a contrasted relief with very variable altitudes where one may observe the inversion of the altitudinal layers of vegetation (case of Michlifene and Jbel Habri) due to the oppositions of the slopes and the accumulation of cold air in the closed depressions. From a bioclimatic point of view, the Azrou forest is of the humid bioclimatic type with a cold variant or sub-humid type with a temperate variant. The climate is also characterized by major storms, making it more favourable for the establishment and development of the cedar grove. The composition of the plant formations of the Azrou forest includes pure cedar stands, mixed cedar, green oak stands, pure green oak stands and reforestation stands of cedar and cypresses (Laaribya, 2016).

\section{Jaaba Forest}

The Jaaba forest has a total area of 10449.16 ha. It receives an annual average rainfall varying between 810 and $976 \mathrm{~mm}$ over a 30-year climatic period with a bioclimatic type ranging from cool sub-humid to wet very cold. In this forest, forest stand typology is defined by the combined effects of the nature of the substrate and the topographic position. Indeed, Zeen oak stands develop on the basalt substrate and in depressions, while on carbonate rock (limestone and dolomite), the type of forest stand is based on green oak. The Jaaba forest includes three types of forest formations: Pure Green Oak, Pure Zeen Oak and a mixture of Green Oak - Zeen Oak (HCEFLCD, 2007).

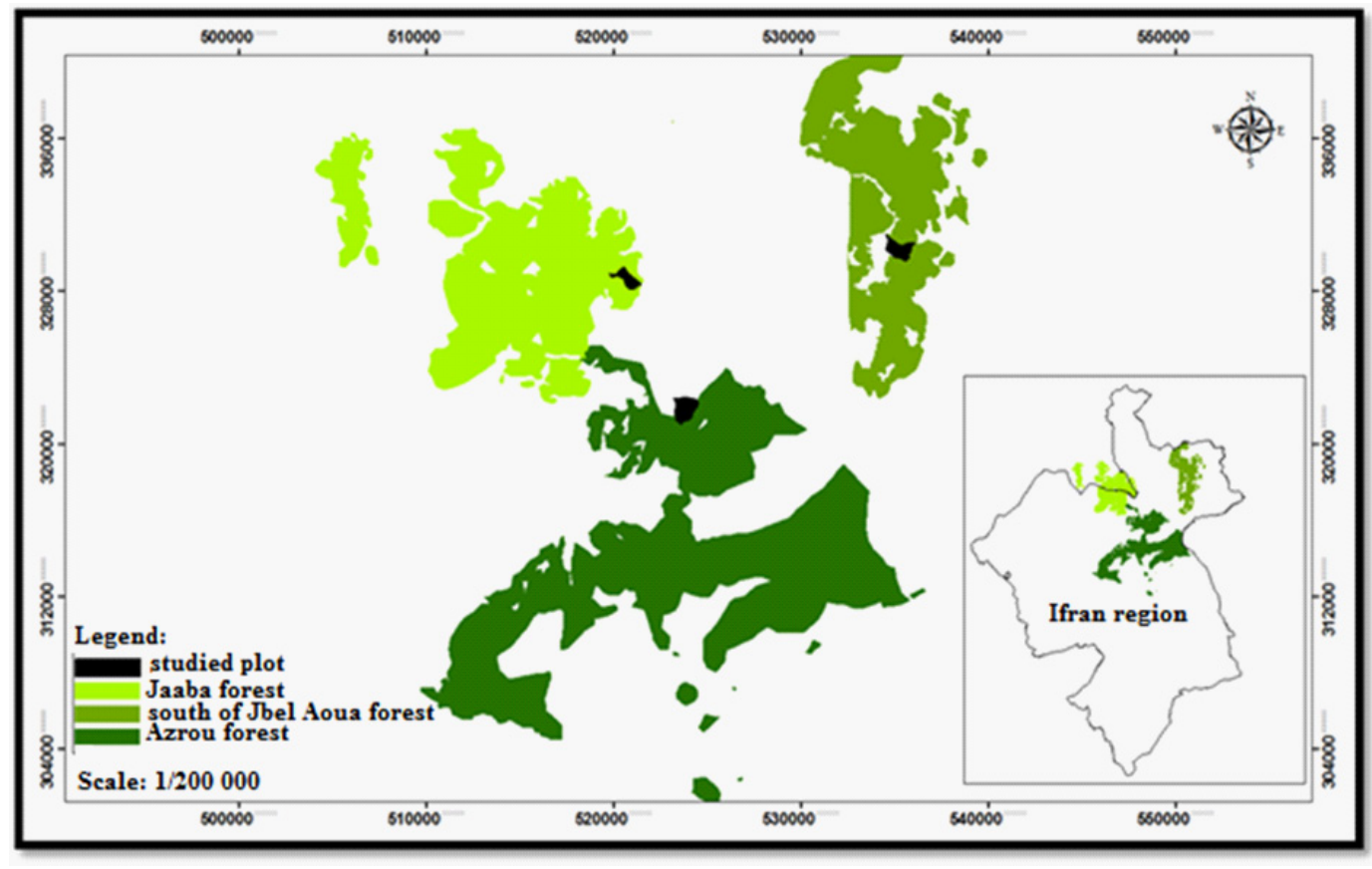

Figure 1. Map of the studied area. 


\section{Methodological Approach}

At the level of each forest, a representative plot was chosen taking into account the topo-climatic position and the type of forest stand. Using a Geographic Information System (GIS) and field validation visits, nine (09) different forest stands were identified (Table 1). At the level of each stand, soil samples from the higher organo-mineral soil $(<30 \mathrm{~cm}$ deep $)$ were collected from six (06) soil site replicates. According to Benjelloun (1997), this layer is the one where root concentration is higher and exchanges between the soil and plant roots are important (Figure 2, 3 and 4).

After sieving the soil samples through $2 \mathrm{~mm}$ meshes, we carried out the following physical and chemical analyses: grain size, bulk density, organic matter, carbon, total nitrogen and acidity $\left(\mathrm{pH}\left(\mathrm{H}_{2} \mathrm{O}\right), \mathrm{pH}(\mathrm{KCl})\right)$. These analyses were carried out in the soil and environmental microbiology laboratory of the Faculty of Science of Meknes.

\section{Determination of Soil Carbon Stock}

The percentage of carbon and the bulk density allow the determination of carbon stocks and organic matter per unit area using the following formula:

$$
q(i)=0.1 \times \operatorname{Ei} \times \mathrm{da}(\mathrm{i}) \times \mathrm{Ci}
$$

Where:

- q (i): soil Corganic content (t/ha),

- Ei: depth (i) (cm),

- da(i): apparent density of the fine fraction $(<2 \mathrm{~mm})$ in depth (i) $\left(\mathrm{g} . \mathrm{cm}^{-3}\right)$,

- Ci: concentration of organic carbon in fine soil for depth (i) $\left(\mathrm{g} \cdot \mathrm{kg}^{-1}\right)$.

$\mathrm{MO}=\mathrm{C}$ org $\mathrm{x} 1.724(\mathrm{t} / \mathrm{ha})$

\section{Statistical Data Analysis}

This step of the work consists of analyzing the data obtained and processing them statistically. Indeed, an analysis of descriptive statistics, mainly means, standard deviations and coefficients of variation, was carried out to explain the variability of sites within the same forest formation (forest stand). Comparisons of formation means for the different studied variables were obtained through a single-criteria analysis of variance (ANOVA 1). The ANOVAs were conducted to verify whether the average carbon stocks of the different strata were significantly different from each other. The assumptions of this test, which are the normality of the distribution and the homogeneity of the variance, were verified beforehand.

\section{Results}

\section{A. Physical Properties}

The results of the physical properties are presented in Table 2.

\section{Texture}

Because texture, directly or indirectly, conditions other physical properties of the soil, it plays an important role in porosity, drainage and especially carbon stocks in the soil (Jessica, 2009). The textural classes of the studied soils are represented in the textural diagram (Figure 5). The most represented textures of these soils are fine silt (S1, S2, S8 and S9), clayeysandy silt (S4 and S6) and clayey-sandy silt (S3, S5 and S7). Thus, most of the forest soils have a rather coarse texture linked to the lithological nature of the parent material. The results of the single-criterion ANOVA show that the proportion of clays is significantly different from one site to another $(\mathrm{p}=0.04)$ for a significance level of $5 \%$.

Table 1. Description of the identified sites.

\begin{tabular}{|c|c|c|c|c|c|c|c|}
\hline Site No. & Localisation & Coordinates & Exposition & Slope (\%) & Altitude (m) & Parent Rock & Forest Vegetation \\
\hline 01 & Jaaba forest & $\begin{array}{c}\text { Long }=-5^{\circ} 10^{\prime} 28^{\prime \prime} \\
\text { Lati }=33^{\circ} 33^{\prime} 7^{\prime \prime}\end{array}$ & NW & 14 & 1593 & Basalt & $\begin{array}{l}\text { Mixture of an adult forest of } \\
\text { zeen oak and green oak }\end{array}$ \\
\hline 02 & Jaaba forest & $\begin{array}{l}\text { Long }=-5^{\circ} 10^{\prime} 38^{\prime \prime} \\
\text { Lati }=33^{\circ} 33^{\prime} 16^{\prime \prime}\end{array}$ & North & 10 & 1562 & Basalt & Mature zeen oak forest \\
\hline $\mathbf{0 3}$ & $\begin{array}{l}\text { South Jbel Aoua } \\
\text { forest }\end{array}$ & $\begin{array}{l}\text { Long }=-5^{\circ} 01^{\prime} 33^{\prime \prime} \\
\text { Lati }=33^{\circ} 34^{\prime} 26^{\prime},\end{array}$ & $\mathrm{NE}$ & 13 & 1745 & Sandy dolomite & Mature green oak forest \\
\hline 04 & $\begin{array}{l}\text { South Jbel Aoua } \\
\text { forest }\end{array}$ & $\begin{array}{l}\text { Long }=-5^{\circ} 01^{\prime 2} 26^{\prime \prime} \\
\text { Lati }=33^{\circ} 34^{\prime} 21^{\prime \prime}\end{array}$ & $\mathrm{NE}$ & 15 & 1750 & Sandy dolomite & Young cedar forest \\
\hline 06 & $\begin{array}{l}\text { South Jbel Aoua } \\
\text { forest }\end{array}$ & $\begin{array}{l}\text { Long }=-5^{\circ} 00^{\prime} 51^{\prime \prime} \\
\text { Lati }=33^{\circ} 34^{\prime} 03^{\prime \prime}\end{array}$ & $\mathrm{NE}$ & 20 & 1768 & Sandy dolomite & $\begin{array}{l}\text { mixture of a young green oak } \\
\text { forest and a mature cedar forest }\end{array}$ \\
\hline 07 & Azrou forest & $\begin{array}{l}\text { Long }=-5^{\circ} 08^{\prime} 31^{\prime \prime} \\
\text { Lati }=33^{\circ} 29^{\prime} 57^{\prime \prime}\end{array}$ & $\mathrm{NE}$ & 20 & 1690 & Basalt & Pure cedar forest \\
\hline 08 & Azrou forest & $\begin{array}{l}\text { Long }=-5^{\circ} 08^{\prime} 39^{\prime \prime} \\
\text { Lati }=33^{\circ} 29^{\prime} 34^{\prime \prime}\end{array}$ & SW & 10 & 1720 & Basalt & Mature zeen oak forest \\
\hline
\end{tabular}




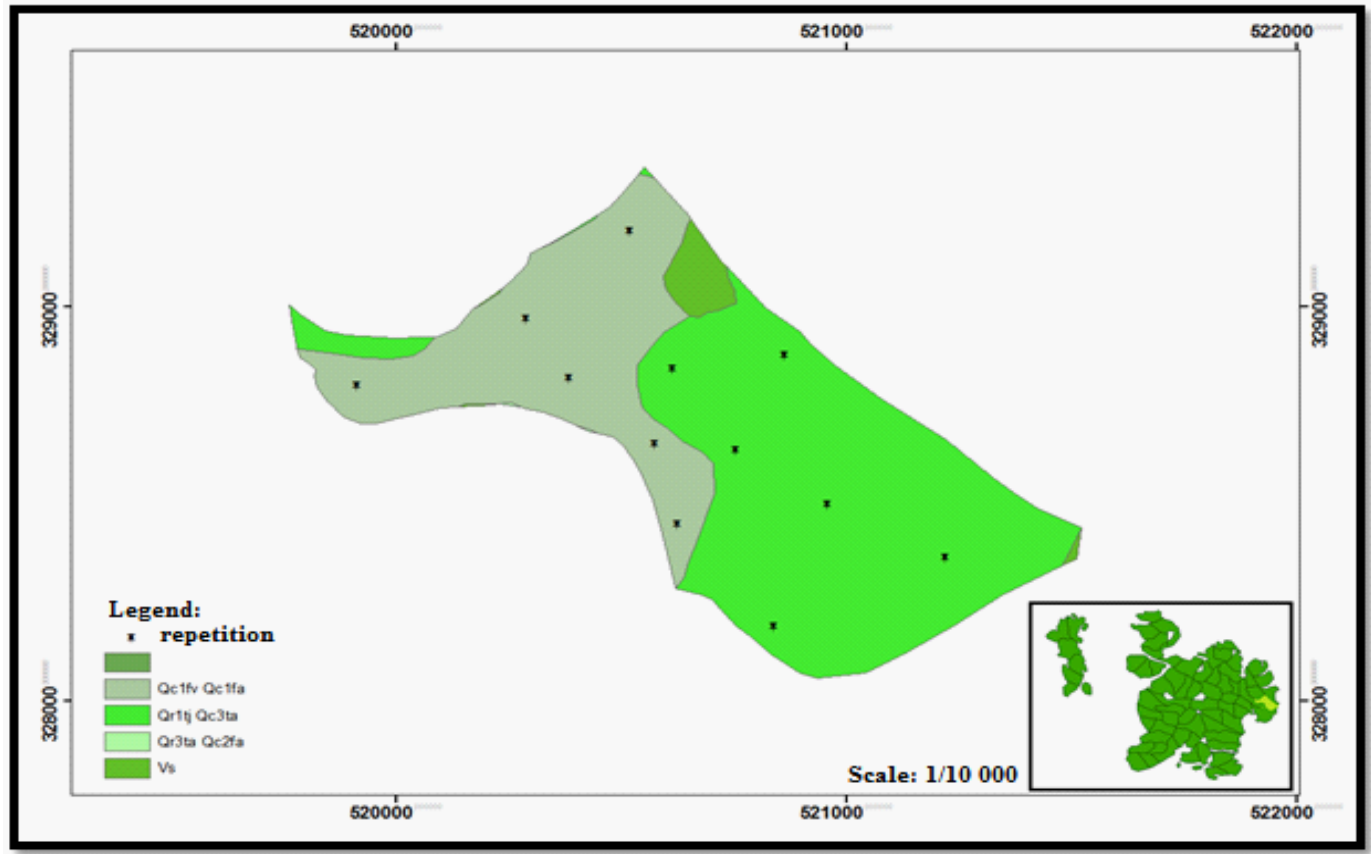

Figure 2. Distribution of soil sampling sites (replicates) in the forest stands of the Jaaba forest.

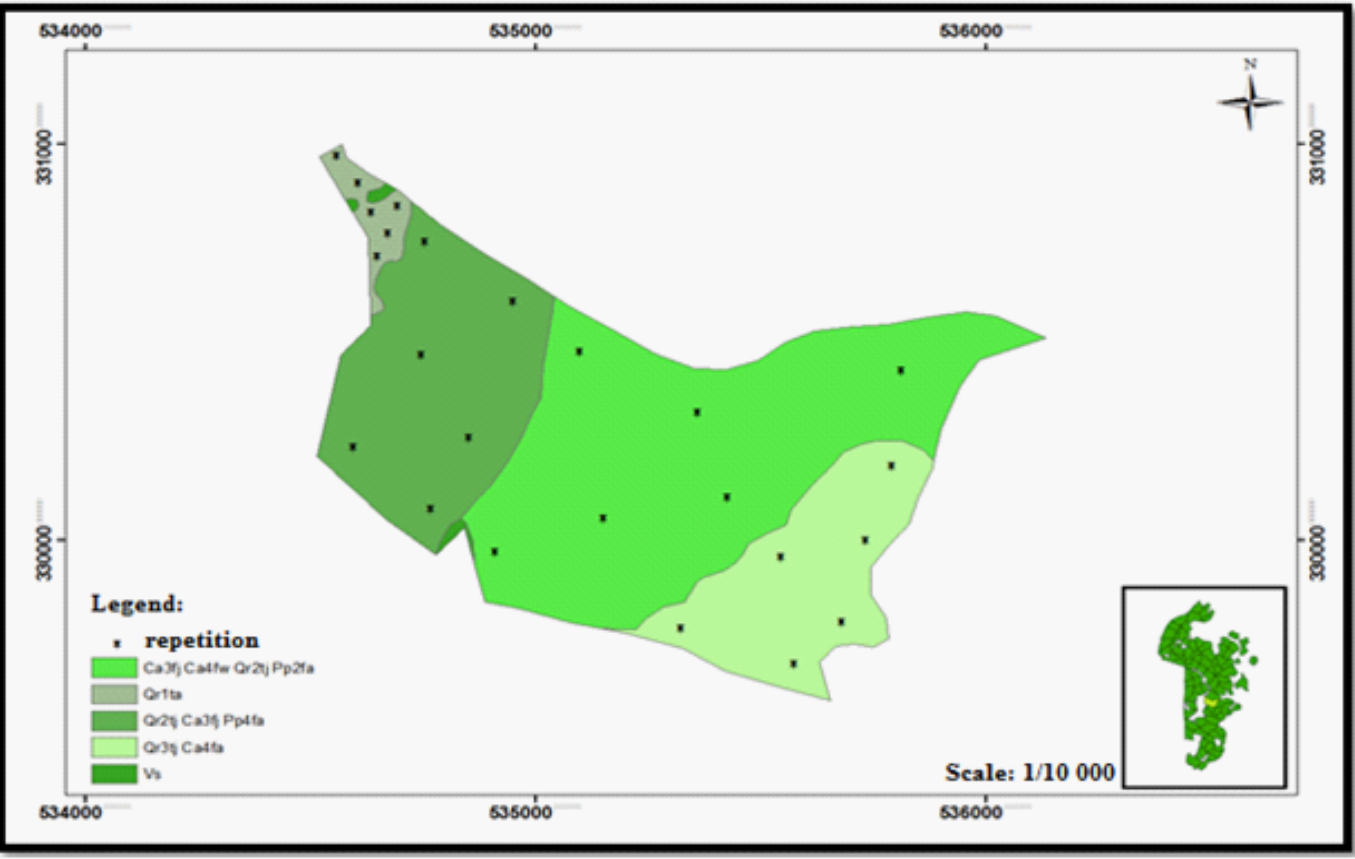

Figure 3. Distribution of soil sampling sites (replicates) in the forest stands of the South of Jbel Aoua forest.

\section{Apparent Density (DA)}

The apparent density of the soil is a necessary parameter for calculating carbon stocks. Values range from 0.74 to $0.85 \mathrm{~g} /$ $\mathrm{cm}^{3}$. Thus, we should say that the studied soils have a good structure allowing them to have a good aeration. The results of the single-criterion ANOVA show that there is no significant difference in the average site density for a significance level of $5 \%$. There is also a high degree of homogeneity within the sites between replicates, expressed by the values of the coefficients of variation, which vary from 3 to $19 \%$.

\section{B. Chemical Properties}

The results of the chemical properties of the soils studied are presented in Table 3.

\section{Carbon and Organic Matter (OM) Concentrations}

The average organic carbon content varies from $4.69 \%$ (S6) to $11.10 \%$ (S9), and the distribution of organic carbon is relatively heterogeneous across all sites based on the values of the coefficient of variation ranging from 29 to $74 \%$. According to 


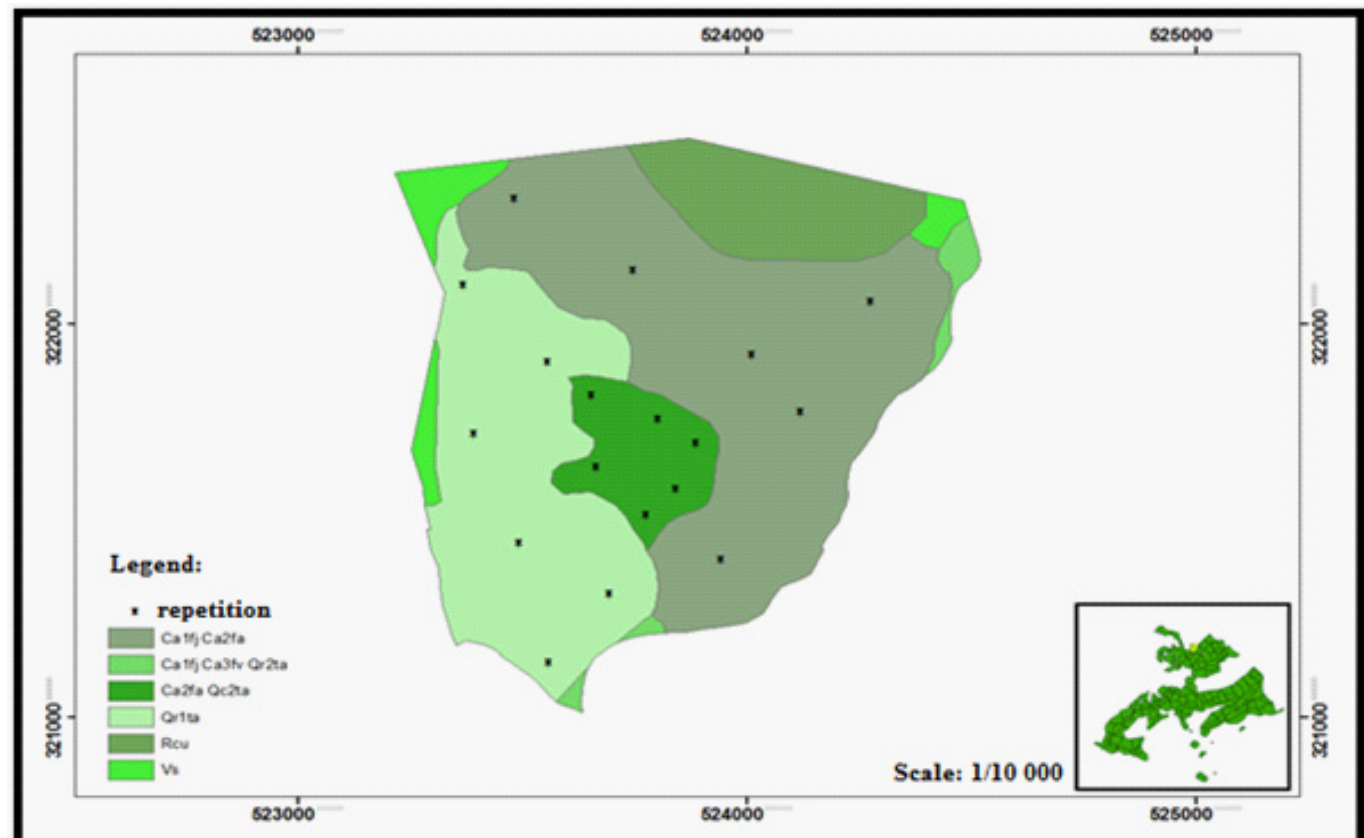

Figure 4. Distribution of soil sampling sites (replicates) in the forest stands of the Azrou forest.

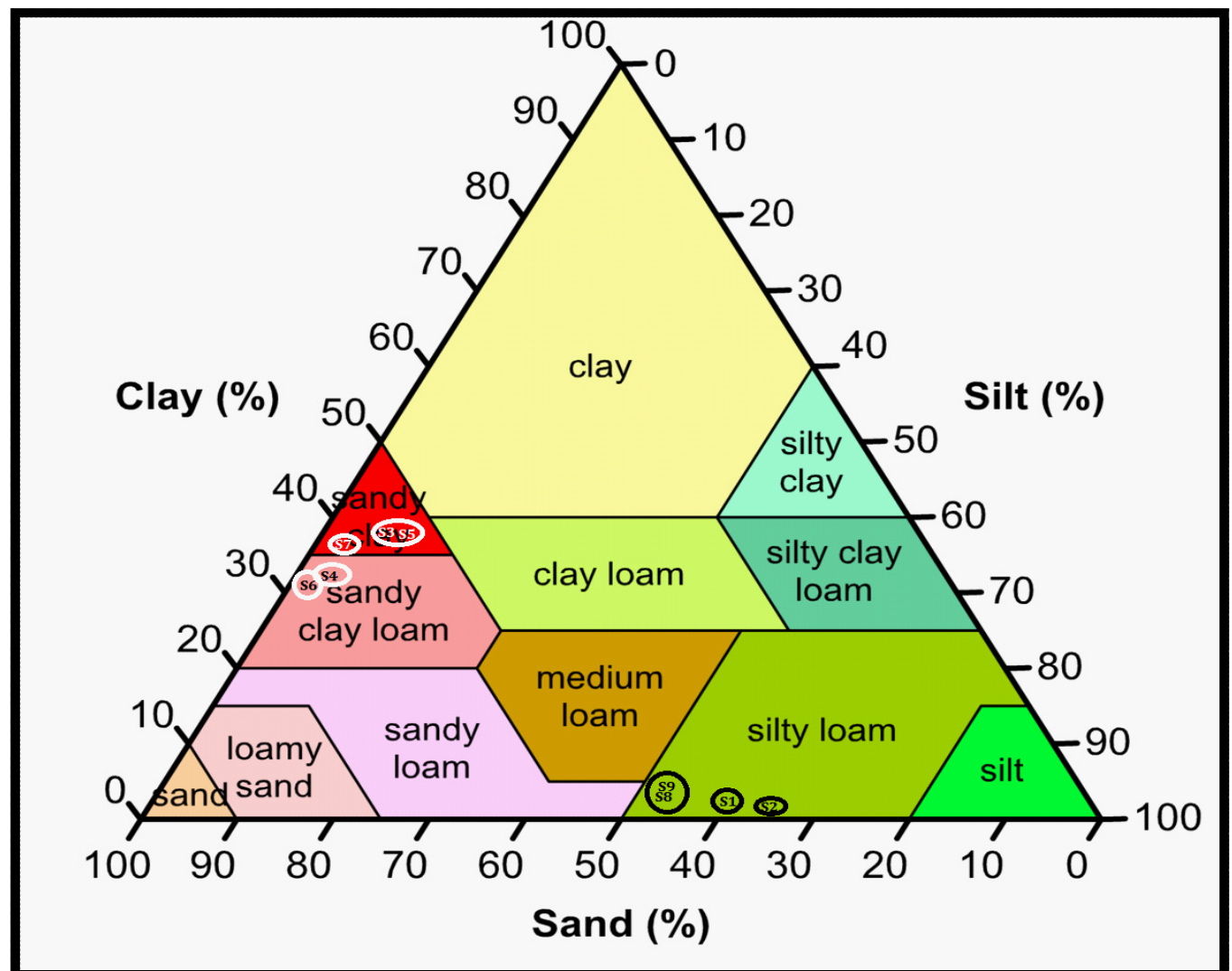

Figure 5. Textural diagram of the studied soils.

the ANOVA results, the averages are significantly different $(\mathrm{p}$ $=0.008)$, hence the influence of the site or forest stand on soil carbon sequestration and thus on soil organic matter reserve. The variation in the percentage of organic matter in the different sites follows the same trend as the carbon concentration since $\mathrm{MO}=\mathrm{C}$ orgx 1.724 (Soltner, 1988).

\section{Total Nitrogen}

The total soil nitrogen in the studied soils (higher soil layer) varies from $0.20 \%$ (S6) to $1.76 \%$ (S9). These values are recorded under mixed forest stands of cedar and green oak growing on a sandy dolomite substrate and under pure green oak stand 


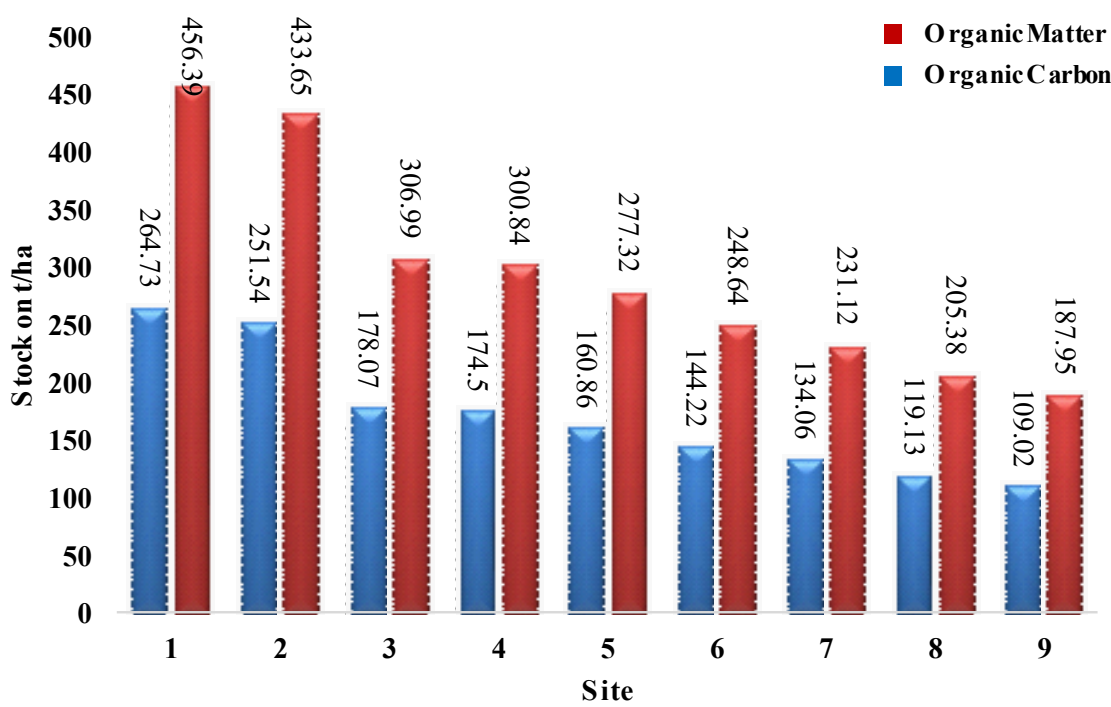

Figure 6. Carbon and organic matter stocks in the studied forest stands in decreasing order.

Table 2. Physical characteristics of the soils studied.

\begin{tabular}{|c|c|c|c|c|c|c|c|c|c|c|}
\hline & & S1 & S2 & S3 & S4 & S5 & S6 & S7 & S8 & S9 \\
\hline \multirow{4}{*}{ 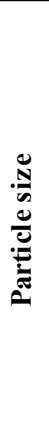 } & $\begin{array}{l}\text { Coarse silt } \\
(\%)\end{array}$ & $\begin{array}{c}26,05 \\
(12) \\
\end{array}$ & $\begin{array}{c}31,33 \\
(21) \\
\end{array}$ & $\begin{array}{r}24,32 \\
(60) \\
\end{array}$ & $\begin{array}{c}21,68 \\
(54) \\
\end{array}$ & $\begin{array}{c}18,15 \\
(76) \\
\end{array}$ & $\begin{array}{c}25,65 \\
(38) \\
\end{array}$ & $\begin{array}{r}29,37 \\
(40) \\
\end{array}$ & $\begin{array}{l}33,97 \\
(20) \\
\end{array}$ & $\begin{array}{c}34,82 \\
(38) \\
\end{array}$ \\
\hline & $\begin{array}{l}\text { Thin sand } \\
\text { (\%) }\end{array}$ & $\begin{array}{c}11,30 \\
(44)\end{array}$ & $\begin{array}{l}9,15 \\
(26)\end{array}$ & $\begin{array}{c}23,83 \\
(53)\end{array}$ & $\begin{array}{c}20,20 \\
(79)\end{array}$ & $\begin{array}{c}22,78 \\
(59)\end{array}$ & $\begin{array}{l}15,30 \\
(73)\end{array}$ & $\begin{array}{c}20,60 \\
(44)\end{array}$ & $\begin{array}{l}13,78 \\
(37)\end{array}$ & $\begin{array}{c}11,02 \\
(41)\end{array}$ \\
\hline & $\begin{array}{l}\text { Coarse sand } \\
(\%)\end{array}$ & $\begin{array}{c}12,72 \\
(25) \\
\end{array}$ & $\begin{array}{c}10,10 \\
(33)\end{array}$ & $\begin{array}{c}22,68 \\
(51)\end{array}$ & $\begin{array}{c}17,68 \\
(88)\end{array}$ & $\begin{array}{c}27,75 \\
(67) \\
\end{array}$ & $\begin{array}{l}17,03 \\
(90) \\
\end{array}$ & $\begin{array}{c}19,77 \\
(48)\end{array}$ & $\begin{array}{l}11,72 \\
(35) \\
\end{array}$ & $\begin{array}{c}14,10 \\
(36) \\
\end{array}$ \\
\hline & Texture & Silty thin & Silty thin & Sandy-clay & Sandy clay silt & Sandy-clay & Sandy clay silt & Sandy-clay & Silty thin & Silty thin \\
\hline & $\begin{array}{l}\text { arent Density } \\
\left(\mathrm{g} / \mathrm{cm}^{3}\right)\end{array}$ & $\begin{array}{l}0,74 \\
(10) \\
\end{array}$ & $\begin{array}{l}0,83 \\
(15) \\
\end{array}$ & $\begin{array}{l}0,80 \\
(19) \\
\end{array}$ & $\begin{array}{l}0,85 \\
(18) \\
\end{array}$ & $\begin{array}{l}0,87 \\
(15) \\
\end{array}$ & $\begin{array}{c}0,85 \\
(9)\end{array}$ & $\begin{array}{l}0,83 \\
(18) \\
\end{array}$ & $\begin{array}{l}0,78 \\
(14) \\
\end{array}$ & $\begin{array}{c}0,79 \\
(3)\end{array}$ \\
\hline
\end{tabular}

S1: Green oak stand mixed with Zeen oak (Jaaba Forest), S2: Zeen oak stand (Jaaba Forest), S3: Green oak stand (Jbel Aoua Forest South), S4 : cedar stand (South of Jbel Aoua Forest), S5: maritime pine stand (South of Jbel Aoua Forest), S6: cedar stand mixed with green oak, S7 : cedar stand (Azou Forest), S8 : Zeen oak stand (Azrou Forest), S9 : green oak stand (Azrou Forest), Values in brackets indicate coefficients of variation in \%, similar letters indicate that the values are not significantly different.

Table 3. Chemical properties of the soils studied.

\begin{tabular}{lccccccccc}
\hline & S1 & S2 & S3 & S4 & S5 & S6 & S7 & S8 & S9 \\
\hline Organic & 8,58 & 10,80 & 12,04 & 10,39 & 8,83 & 8,08 & 12,87 & 18,89 & 19,14 \\
matter (\%) & $(38)$ & $(74)$ & $(39)$ & $(44)$ & $(64)$ & $(57)$ & $(29)$ & $(41)$ & $(31)$ \\
& $\mathrm{ab}$ & $\mathrm{ab}$ & $\mathrm{ab}$ & $\mathrm{ab}$ & $\mathrm{ab}$ & $\mathrm{a}$ & $\mathrm{ab}$ & $\mathrm{b}$ & $\mathrm{b}$ \\
\hline Carbon (\%) & 4,98 & 6,27 & 6,99 & 6,03 & 5,12 & 4,69 & 7,46 & 10,96 & 11,10 \\
& $(38)$ & $(74)$ & $(39)$ & $(44)$ & $(64)$ & $(57)$ & $(29)$ & $(41)$ & $(31)$ \\
& $\mathrm{ab}$ & $\mathrm{ab}$ & $\mathrm{ab}$ & $\mathrm{ab}$ & $\mathrm{ab}$ & $\mathrm{a}$ & $\mathrm{ab}$ & $\mathrm{b}$ & $\mathrm{b}$ \\
\hline Total & 0,3 & 0,60 & 0,70 & 0,63 & 0,52 & 0,20 & 0,89 & 0,28 & 1,76 \\
Nitrogen (\%) & $(25)$ & $(107)$ & $(37)$ & $(48)$ & $(70)$ & $(121)$ & $(137)$ & $(131)$ & $(38)$ \\
& $\mathrm{a}$ & $\mathrm{ab}$ & $\mathrm{ab}$ & $\mathrm{ab}$ & $\mathrm{ab}$ & $\mathrm{ab}$ & $\mathrm{ab}$ & $\mathrm{ab}$ & $\mathrm{b}$ \\
\hline C/N & 16,6 & 10,45 & 9,98 & 9,57 & 9,84 & 23,45 & 8,38 & 39,14 & 6,31 \\
& $(43)$ & $(121)$ & $(89)$ & $(81)$ & $(175)$ & $(101)$ & $(103)$ & $(120)$ & $(97)$ \\
\hline pH (H2O) & 6,52 & 6,46 & 7,23 & 7,21 & 7,37 & 7,09 & 6,51 & 6,10 & 6,33 \\
& $(3)$ & $(2)$ & $(2)$ & $(4)$ & $(4)$ & $(6)$ & $(3)$ & $(3)$ & $(6)$ \\
\hline pH (Kcl) & 5,84 & 6,11 & 6,81 & 6,61 & 6,98 & 6,52 & 5,98 & 5,50 & 5,37 \\
& $(2)$ & $(8)$ & $(3)$ & $(4)$ & $(3)$ & $(5)$ & $(1)$ & $(5)$ & $(3)$ \\
\hline
\end{tabular}

S1: Green oak stand mixed with Zeen oak (Jaaba Forest), S2: Zeen oak stand (Jaaba Forest), S3: Green oak stand (Jbel Aoua Forest South), S4 : cedar stand (South of Jbel Aoua Forest), S5: maritime pine stand (South of Jbel Aoua Forest), S6: cedar stand mixed with green oak, S7: cedar stand (Azou Forest), S8: Zeen oak stand (Azrou Forest), S9: green oak stand(Azrou Forest), Values in brackets indicate coefficients of variation in $\%$, similar letters indicate that the values are not significantly different. 
Table 4. Soil Organic Carbon Stock (SCOS) at the studied soils.

\begin{tabular}{lccccccccc}
\hline & S1 & S2 & S3 & S4 & S5 & S6 & S7 & S8 & S9 \\
\hline OCT S tock (t/ha) & $\begin{array}{c}109,02 \\
\text { ad }\end{array}$ & $\begin{array}{c}144,22 \\
\text { ad }\end{array}$ & $\begin{array}{c}174,50 \\
\text { abc }\end{array}$ & $\begin{array}{c}160,86 \\
\text { abc }\end{array}$ & $\begin{array}{c}134,06 \\
\text { abc }\end{array}$ & $\begin{array}{c}119,13 \\
\text { abc }\end{array}$ & $\begin{array}{c}178,07 \\
\text { abc }\end{array}$ & $\begin{array}{c}251,54 \\
\text { be }\end{array}$ & $\begin{array}{c}264,73 \\
\text { ce }\end{array}$ \\
\hline $\begin{array}{l}\text { Organic Matter } \\
\text { Stock (t/ha) }\end{array}$ & 187,95 & 248,64 & 300,84 & 277,32 & 231,12 & 205,38 & 306,99 & 433,65 & 456,39 \\
\hline CV (\%) & $(32)$ & $(60)$ & $(60)$ & $(57)$ & $(75)$ & $(56)$ & $(18)$ & $(40)$ & $(34)$ \\
\hline
\end{tabular}

S1: Green oak stand mixed with Zeen oak (Jaaba Forest), S2: Zeen oak stand (Jaaba Forest), S3: Green oak stand (Jbel Aoua Forest South), S4: cedar stand (South of Jbel Aoua Forest), S5: maritime pine stand (South of Jbel Aoua Forest), S6: cedar stand mixed with green oak, S7: cedar stand (Azou Forest), S8: Zeen oak stand (Azrou Forest), S9: green oak stand (Azrou Forest), Values in brackets indicate coefficients of variation in \%, similar letters indicate that the values are not significantly different.

on basalt parent rock, respectively the results, obtained by the ANOVA using only one criterion, generate a statically significant difference between the different sites $(p=0.04)$. In terms of fertility, the recorded values showed that all sites are considered to be very rich in total nitrogen according to the standard found by Dabin (1963) ranging from 0.15 to $0.25 \%$.

\section{C/N Ratio}

The carbon-nitrogen ratio of a soil is determined as the weight ratio between the amount of organic carbon and nitrogen (Gobat et al. 2003). It allows the evaluation of the quality of organic matter as well as the estimation of the importance of humification and mineralization processes acting in soils (Jessica 2009). Lafond et al. (1992) and Akselsson et al. (2005) mentioned the $\mathrm{C} / \mathrm{N}$ ratio as a good indicator for assessing carbon sequestration in soils. A high $\mathrm{C} / \mathrm{N}$ ratio represents a low rate of carbon decomposition since decomposing organisms use nitrogen which quickly becomes limiting. A low $\mathrm{C} / \mathrm{N}$ ratio indicates a high nitrogen concentration and a high degree of decomposition. The results obtained from the $\mathrm{C} / \mathrm{N}$ ratio range from 6.31 (S9) to 39.14 (S8). Taking these values into account, the majority of which are less than 10, it can be said that the biological activity is good and that the nitrogen mineralization process outweighs the immobilization process by soil microorganisms.

\section{Acidity}

The $\mathrm{pH}\left(\mathrm{H}_{2} \mathrm{O}\right)$ analysis results (Table 3$)$ show that the studied soils have $\mathrm{pH}$ values ranging from 6.10 to 7.37 indicating a weakly acidic to neutral chemical environment. The $\mathrm{pH}(\mathrm{KCl})$ is, always lower than the $\mathrm{pH}\left(\mathrm{H}_{2} \mathrm{O}\right)$, and varies between 5.50 and 6.98. According to the single-criterion ANOVA, there is a very significant difference between the means $(\mathrm{P}=0.000)$ showing the effect of forest composition on soil acidity, with a high homogeneity within sites between repetitions which values of coefficients of variation vary between 1 and $6 \%$.

\section{Soil Organic Carbon Stock (SOCS)}

The ecological variables as well as the physical and chemical properties of the soil may influence the accumulation of organic carbon in the soil. The results of SOCS in the studied soils are presented in Table 4 and highlighted in Figure 6. The
ANOVA results generate a significant difference between sites $(p=0.012)$ in SOCS, hence the effect of the site and the forest type on the variation in SOCS. The quantities of carbon sequestered in the studied soils ranged from 109.02 to $264.73 \mathrm{t} / \mathrm{ha}$. The highest stock is found under green oak and zeen oak deciduous forest trees (S8 and S9) on a basaltic parent rock, followed by cedar resinous trees on a basaltic substrate (S7). This mixing of stands may have led to the variability in soil bed quality, rooting depth of tree species and soil chemistry, which may also influence carbon storage. A student $\mathrm{T}$ test comparing the means for independent samples was performed, showing a significant difference $(p=0.012)$ between the means of SOCS in a basaltic and sandy dolomite substrate, hence the effect of the nature of the lithological material on the variation in SOCS under the same forest species. This is the case for S3 (green oak on sandy dolomite with a $\mathrm{SCOS}=174.50 \mathrm{t} / \mathrm{ha}$ ) and $\mathrm{S} 9$ (green oak on basalt with a $\mathrm{SOCS}=264.73 \mathrm{t} / \mathrm{ha}$ ).

\section{Discussion}

The forest soils contribute to about $70 \%$ of the carbon dioxide exchanges between the biosphere and the atmosphere. These quantities are mainly produced by the decomposition of organic matter and root respiration (Jessica 2009). These processes vary according to several parameters including climate, vegetation type, soil physico-chemical characteristics (Conant and Paustian 2001), frequency of natural disturbances and development. It is therefore difficult to accurately estimate organic carbon stocks at the regional level and to obtain quality empirical data that accurately represent this heterogeneity (Kulmatiski et al. 2003 in Jessica 2009).

The obtained results show that the forest soils of the Central Middle Atlas have a high carbon sequestration capacity. Indeed, the average organic carbon stock at the level of the studied forests is about 231.45 t/ha in the Azrou forest, $147.14 \mathrm{t} / \mathrm{ha}$ in the South of Jbel Aoua forest and $126.62 \mathrm{t} / \mathrm{ha}$ in the Jaaba forest in the first thirty centimetres of soil. This variation depends on the nature of the soil in the study area. The carbon stocks found in this layer under the green oak stands are higher than those observed by Boulmane (2010), which are of the order of $63 \mathrm{t} / \mathrm{ha}$ and $47 \mathrm{t} /$ ha respectively in the forests of Tafechna and Reggada considered relatively degraded. This SCOS value is still higher than that recorded under cork oak stands in the Maamora forest (78 t/ha) (Oubrahim 2015) and in the Moroccan Rif (100 t/ha) (Sabir et al., 2002). These strong potentialities of the studied 
forest soils in terms of carbon sequestration can be explained by the large quantities of litter returned to the ground by the existing forest formations in the studied sites, and by the presence of allophanes resulting from the alteration of basaltic rocks (Jaaba and Azrou sites) and calcium $\left(\mathrm{Ca}^{++}\right)$resulting from the alteration of limestone and dolomite (Jbel Aoua site), which have the ability to fix and retain organic matter in a stable state in the soil (Benjelloun 2017).

A similar study by Eglin (2005) and Lecointe et al (2005) in British forests estimated an SOCS in the organic layer (depth $<$ $30 \mathrm{~cm}$ ) of 136 and $153 \mathrm{t} / \mathrm{ha}$ respectively is still below the SOCS found in the study area.

A SOCS was evaluated in a Canadian forest by Jessica (2009) below 5 types of plant formations with values ranging from 61 to $133 \mathrm{t} / \mathrm{ha}$, the highest of which is still observed under hardwood in the first organic layer of the soil $(<30 \mathrm{~cm})$, and highlighted the effect of plant material on soil organic carbon accumulation.

\section{Conclusion}

The purpose of this study was to determine carbon stocks under different forest formations in the Central Middle Atlas. With regard to the results obtained, it can be said that there is spatial variability in carbon stocks in the study area and that this may be explained by the different nature of the forest formations concerned. However, several factors contribute to the understanding of these stocks and it will be essential to consider them in subsequent analyses. Indeed, the best SOCS are observed below the hardwoods (Green oak and Zeen oak) followed by cedar-based softwoods on a basaltic substrate. Mixed strata showed low carbon accumulations. The presence of allophanes and exchange earth bases $(\mathrm{Ca}++$ and $\mathrm{Mg}++)$ in the soil contributes to the fixation and maintenance of soil organic matter in a stable state.

\section{References}

Akselsson C, B Berg, V Meentemeyer, and O Westling (2005) Scaling up carbon sequestration rates in organinc layers of boreal and temperate forest soils -example Sweden». Global Ecology and Biogeography 14: 77-84.

Benjelloun H (2017) Cours de pédologie forestière, 4ème année, INFI, Salé. Maroc. [In French]

Benjelloun H (1997) Impactdes différentes espèces de reboisement, du chêne liège et de l'absence du couvert végétal sur les propriétes physicochimiques des sols dans la Maamora occidentale. Ann. Rech. For. Maroc, T(30), 17-31p. [In French]

Bernoux, M. et al, (2005) Gaz à effet de serre et stockage du carbone par les sols : inventaire au niveau du Brésil, Cahiers Agriculture 14: 96-100. [In French]

Boulmane M, M Makhloufi, JP Bouillet, L Saint-André, B Satrani, M Halim, and S Elantry-Tazi (2010) Prédiction du stock de carbone organique dans les Quercus ilex du Moyen Atlas Marocain. Acta bot. Gallica 157: 451-467. [In French]

Conant RT, K Paustian, and Elliott (2001) Grassland management and conversion into grassland: Effects on soil carbon. Ecological Applications 2: 343-355.

Dabin B (1963) Appréciation des besoins en phosphore dans les sols tropicaux. Les formes de phosphore dans les sols de Cote d'Ivoire. Cah. ORSTOM, sér. Pédol., pp. 27-42. [In French]

Eglin T (2005) Impact de l'hydromorphie et la topographie sur la variabilite spatiale des stocks de carbone en foret de Fougeres (Ille-etVilaine) [Impact of waterlogging and topography on the spatial variability of carbon stocks in the forest of Fougeres (Ille-et-Vilaine)]. These Institut National Agronomique, Paris-Grignon, France, pp. 50. [In French]

Gobat JM et al. (2003) Le sol vivant: Bases de pédologie, Biologie des sols. Presses polytechniques et universitaires romandes (Ed), p. 528. [In French]

HCEFLCD (2007) Etude d'aménagement concerté des forêts du Moyen Atlas. [In French]

Jessica L et al. (2009) Caractérisation des stocks de carbone de 5 types de formations végétales dans un secteur du bassin versant de la rivière eastmain, baie james. Mémoire de maitrise. Université du québec. Montréal. Canada. [In French]

Kulmatiski A, Vogt, TG Siccama, and KH Beard (2003) Detecting nutrient pool changes in rocky forest soils. Soil Science Society of America Journal 67: 1282-1286.

Laaribya S (2016) Dynamique et accroissement radial du Cèdre de de l'Atlas (Cedrus atlantica) - Cas de la forêt d'Azrou (Maroc), Nature et Technology, B- Sciences Agronomiques et Biologiques, pp. 2336. [In French]

Lafond R, C Claude, and JP Ducruc (1992) Pédologie forestière, MontRoyal (Québec): Modulo, 146 p. [In French]

Laganière J, DA Angers, D Paré, Y Bergeron, and HYH Chen (2011) Black Spruce Soils Accumulate More Uncomplexed Organic Matter than Aspen Soils. Soil Sci. Soc. Am. J. 75: 1125.

Lecointe S, C Nys, C Walter, F Forgeard, S Huet, P Recena, S Follain (2005) Estimation of carbon stocks in a beech forest (Fougeres Forest): extrapolation from plots to the whole forest. Annals of Forest Science 25: 432-451.

Liski J and CJ Westman (1997) Carbon storage inforest soil of finland. 1 - Effect of thermoclimate. Biogeochemistry 36: 239-260.

Liski J (1999) $\mathrm{CO}_{2}$ emissions from soil in response toclimatic warming are overestimated: the decomposition of old soil organic matter is tolerant temperature. Ambio 28: 171-174.

Oubrahim H (2015) Carbon storage in degraded cork oak (Quercus suber) forests on flatlowlands in Morocco. i Fo r e s t Biogeosciences and Forestry. p. 1-13.

Post W.M., W.R. Emanuel, P.J. Zinke \& G. Stangenberger, (1982) Soil carbon pools and worde life zones. Nature 298: 156-159.

Sabir M, and E Roose (2002) Effects of soil types and vegetal cover on soil carbon stock and runoff/ erosion risks in the western Rif's Mediterranean mountains (Morocco). Bulletin Reseau Erosion, Institut de Recherche pour le Developpement, Montpellier 22: 144-154.

Schlesinger WH (1977) Carbon balance in terrestrial detritus. Ann. Rev. Ecol. Syst. 8: 51-81.

Soltner D (1988) Les bases de la production végétale : Tome 1, le sol. Sciences et Techniques Agricoles (16e édition), Angers, Saintegemmes-sur-Loire, France, p. 469. [In french]

Watson RT, H Rhodhe, F Oeschger, and U Siegenthaler (1990) Greenhouse gases and aerosols. In: Climate change, the IPCC scientif assessment. J.T. Houghton, G.J. Jenkins \& J.J. Ephraums (eds), Cambridge University Press, p. 40. 